Review Article

\title{
Skills in Biocatalysis are Essential for Establishing a Sound Biotechnological Base in India
}

\author{
MUNISHWAR NATH GUPTA*,1 and JOYEETA MUKHERJEE ${ }^{2}$ \\ ${ }^{1}$ Department of Biochemical Engineering and Biotechnology, Indian Institute of Technology Delhi, Hauz \\ Khas, New Delhi 110 016, India \\ ${ }^{2}$ Department of Chemistry, Indian Institute of Technology Delhi, Hauz Khas, New Delhi 110 016, India
}

(Received on 24 May 2015; Revised on 13 July 2015; Accepted on 17 July 2015)

\begin{abstract}
Techniques developed by enzymologists and protein chemists have been indispensible in many areas of biotechnology. Bio-separation of proteins, biocatalyst engineering and medium engineering are important examples of this. Our understanding of enzyme specificity has helped us in gaining insight into catalytic promiscuity. This, along with the possibility of carrying out biocatalysis in organic solvents has widened the scope of using enzymes for organic synthesis.
\end{abstract}

Reestablishing a strong base in enzymology is crucial towards creating a strong base for the field of biotechnology in India.

Keywords: Affinity Chromatography; Affinity Precipitation; Expanded Bed Chromatography; Three Phase Partitioning; Cross-Linked Enzyme Aggregates (CLEA); Protein Coated Micro Crystals (PCMC); Protein Cross-Linking; Applied Bio-Catalysis

"By three methods we may learn wisdom: First, by reflection, which is noblest; Second, by imitation, which is easiest; and third by experience, which is the bitterest"

- Confucius

\section{Introduction}

Quite a few aspects of biotechnology involve production and applications of enzymes. In the old days, most of these aspects were covered under industrial enzymology (Godfrey and Reichelt, 1983). Gradually, a more broad based term 'applied biocatalysis' came into vogue (Straathof and Adlercreutz, 2000) which was an interface between enzymology and biochemical engineering. This phase was characterized by few new developments: (1) As a result of the rDNA technology, our capability to produce mutant properties grew exponentially. There was a scramble to produce proteins at a lower cost. The stakes were no longer limited to low cost industrial grade enzymes. Costlier proteins used in molecular biology, diagnostics and biosensors and pharmaceutical proteins/enzymes could be produced by cloning and their properties tailored to suit the applications. The result was a paradigm shift in the downstream processing methods. Shorter and efficient protocols emerged. Affinity chromatography, rather than being a 'polishing' step at the end, was promoted to the earlier steps of purification. In fact, upstream and downstream processing steps were integrated (Gupta, 2002; Przybycien et al., 2004; Mondal et al., 2006). (2) It was realized that enzymes could be used in non aqueous media (Carrea and Riva 2000; Gupta 2000; Patel 2000; Vulfson et al., 2001). This opened up novel applications; especially in the synthesis of chiral compounds. Table 1 lists some of the milestones in the area of applied biocatalysis.

It is remarkable how much enzymology contributed to all this.

The present review attempts to emphasize the importance of the skills which are part of the toolbox

*Author for Correspondence: E-mail: munishwar48@yahoo.co.uk; Tel: +91-11-26591503 
Table 1: Milestones in Applied Biocatalysis

\begin{tabular}{ll}
\hline Milestones & Comments \\
\hline
\end{tabular}

Early era of industrial enzymology

Chemical modification by mono-functional and bi-functional reagents

rDNA technology for altering proteins desirable biocatalysts

Emergence of more efficient techniques for downstream processing of proteins

Protein separation in the post-genomic era

Enzyme Immobilization

Enzyme use in neat organic solvents

Enzyme deactivation models

Enzymes as reverse micelles

Enzyme use in biosensors

The era of White biotechnology and biorefinery

The discovery of the concepts of moonlighting proteins and enzyme promiscuity
Enzymes were used in detergents (van Ee et al., 2010), food processing industries, leather industries, textile industries. Use of enzymes in starch degradation and edible oil extraction needs a special mention. (Straathof and Adlercreutz 2000; Bommarius and Riebel 2004; Hou 2005; Polaina and MacCabe 2007)

Before the advent of protein engineering, chemical modification was widely used for protein stabilization. (Means and Feeney 1990; Tyagi and Gupta 1998)

Protein engineering and directed evolution are now widely used to alter proteins to get (Nosoh and Sekiguchi 1993; Carey 1996; Arnold and Georgiou 2003a,b)

With time upstream and downstream processes have merged.

(Walter and Brooks 1985; Chase 1994; Bruce et al., 1999; Mattiasson 1999; Roy and Gupta 2001; Fexby and Bulow 2004)

2-D gel electrophoresis and mass spectroscopy to analyse proteomics has revolutionized the scene. (Lesley 2001; Roy et al., 2006)

Three groups shaped this area in its formative years: Katchalski in Israel (he became the president of Israel later) (Goldstein and Katchalski-Katzir 1976; Solomon et al., 1984a,b); Klaus Mosbach and Bo Mattiasson in Sweden (Srere et al., 1973; Mosbach 1976, 1980; Nilsson and Mosbach 1981; Mattiasson 1983; Mattiasson 1988) Berezin's group in Moscow was the third one (Berezin 1978; Mozhaev et al., 1987; Martinek and Mozhaev 1993). Current work is adequately discussed at many places (Cao 2005; Minteer 2011; Guissan 2013)

This made it possible to use inexpensive hydrolases for organic synthesis. (Zaks and Klibanov 1988; Mattiasson and Adlercreutz 1991; Halling 1994; Patel 2000; Halling 2000; Klibanov 2001)

Most people wrongly give half lives without analysing the kinetics of deactivation. Sadana's work needs to be known more widely. (Sadana 1991, 1993)

This is another approach in low water enzymology. (Luisi 1985; Larsson et al., 1987; Adlercreutz et al., 1988)

Immobilization allows enzymes to interface with transducers. (Yarapolov et al., 1984; Guilbault 1988; Danielsson and Mosbach 1988; Ramanathan et al., 2000)

To develop processes which do not need "end of pipe" waste remediation is the 'mantra' of white biotechnology. (Jaeger 2004; Sell and Ulber 2006; Gupta and Raghava 2007; Wright and Evans 2008; Boodhoo and Harvey 2013)

This is challenging the concept of one enzyme-one activity. (Hult and Berglund 2007; Jeffery 2009; Khersonsky and Tawfik 2010; Busto et al., 2010; Gupta et al., 2011; Kapoor and Gupta 2012; Arora et al., 2014b) of an enzymologist (and protein chemist) in shaping the contours of the developments in bioseparation and biocatalysis.

Any country that wants to be self-reliant and develop as a global hub for biotechnological products cannot afford to ignore the manpower development in applied biocatalysis. It is also vital that we evolve better mechanisms for marketing what is labelled as "Made in India". That applies to Indian ideas and innovations as well.

\section{Designing Affinity Based Methods for Protein Separation and Refolding}

One key change in the protein production process in the last decade or so has been that upstream steps 
have fully integrated with downstream steps (Gupta and Mattiasson, 1994; Walker, 2002). Use of the affinity based separation strategies played an important role in this landmark innovation. Fusion tags (most familiar example is poly His tag) enable direct application of affinity chromatography called immobilized metal affinity chromatography (IMAC) (Porath, 1975; Mbrabet and Vijaylakshmi, 2002; Mondal and Gupta, 2006). While the trend is to use available commercial kits or commercially available affinity media; it helps to understand the design of the affinity media. In general, an affinity matrix is a bioconjugate of an affinity ligand which is attached to a polymeric matrix. The target protein recognizes the affinity ligand, binds it in a somewhat selective fashion and can be eluted often as a pure protein. Often, even the elution protocol can bring in considerable selectivity (Mondal et al., 2006). With poly His-tagged proteins, the metal releases a coordinated ligand (like, even the water molecule) and complexes with imidazole side chains of the histidine residues. The elution can be with an isocratic mode with a low $\mathrm{pH}$ buffer or imidazole solution. One may benefit from a selective elution by using a gradient elution with a $\mathrm{pH}$ gradient or a imidazole gradient. It is often not realised that the choice of the metal ion is important in achieving a successful or best possible separation. The most frequently used metal ions are $\mathrm{Ni}^{2+}, \mathrm{Cu}^{2+}$ and $\mathrm{Co}^{2+}$ (Vijaylaksmi, 2002). However, $\mathrm{Ca}^{2+}$ and $\mathrm{Fe}^{3+}$ have also been employed (Burgess and Deutscher, 2009; Mbrabet and Vijaylakshmi, 2002). Broadly, one can use an activation approach, wherein, a matrix is activated prior to the addition of the affinity ligand. Alternatively, coupling chemistry involving condensing reagents can also be used. Many options for the conjugation of proteins are readily available (Hermanson et al., 1992; Gupta and Mukherjee, 2013).

Few observations which may be of practical value are listed below:

- The cyanogen bromide coupling can be used for linking an affinity ligand to a matrix containing either a single $-\mathrm{OH}$ or vicinal $-\mathrm{OH}$ groups (Axen et al., 1967). The method results in an affinity media having cationic charges in addition to/irrespective of the nature of the ligand.

- Both coupling reagents, simple epichlorohydrine and bisepoxyranes (like 1,4-butanediol-bisepoxypropyl-ether) use the same chemistry. A bisepoxyrane creates a larger spacer. These reagents have the additional advantage of automatically creating a spacer between the ligand and the matrix. Both classes of reagents require highly basic $\mathrm{pH}$. This precludes this for the applications, where ligands labile at high basic $\mathrm{pH}$ are involved. Also, matrices like polyacrylamide cannot be used for the same reason.

- Malaprade reaction, i.e., periodate oxidation of vicinal $-\mathrm{OH}$ groups has to be followed by reduction to stabilise the Schiff bases. Sodium cyanoborohydride is a milder reducing agent as compared to sodium borohydride. If -S-Sbridges are present in affinity ligands/proteins, one should run controls to check the lability of these bonds before opting for this method. For oriented immobilisation particularly of antibodies (Solomon et al., 1986; O'Shannesy and Hoffman, 1987; Gupta and Mattiasson, 1992), this is fairly useful chemistry. Same is the case for immobilising any glycoproteins.

- Triazine chemistry is one of the mildest and convenient coupling procedures. The use of dyes as affinity ligands started with triazine dyes and uses this chemistry. As biomimetic dyes are valuable affinity ligands (Sousa and AngelaTaipa, 2014), this chemistry would always be found useful. There are however two negative features. The reagent, trichloro-s-triazine is insoluble in water, so aqueous organic co-solvent mixture has to be used as the coupling media. Also, both anionic and $\pi-\pi$ nonspecific interactions makes the elution of the protein difficult.

- Carbodiimide coupling with EDC (1-Ethyl-3-(3dimethylaminopropyl) carbodiimide) is a convenient protocol to form amide link. This chemistry was developed as a part of major efforts to synthesize peptides chemically. 
- $\quad N$-hydroxy succinimide (NHS) esters can also be used to link polyhydroxy supports to amino groups of the protein. For washing/storage, it is better to avoid methanol, as it has been shown to trans-esterify with NHS esters (Hermanson et al., 1992).

- During any chromatography, it is advisable not to delay elution of a bound protein. Invariably, secondary non-specific interactions tend to make the binding irreversible.

- The choice of the buffer is important as functional groups present in the buffer components may react with the reagent. For example, Tris $\mathrm{HCl}$ buffer should be avoided during EDC coupling. Often these precautions are overlooked and this creates many artefacts, which results in unsuccessful outcomes. Similarly, if $\mathrm{Ca}^{2+}$ are required to stabilize a protein ligand, both phosphate buffer and EDTA cannot be used.

Affinity based separations are not limited to the use of chromatography. A special mention must be made, to the use of smart polymers in affinity based separations. As most of the early work in this area has been reviewed periodically including an earlier review in this very journal (Roy and Gupta, 2002a), the discussion here will be limited to briefly mentioning recent work on simultaneous purification and refolding of proteins by using either affinity precipitation or macro-affinity facilitated three phase partitioning (MLFTPP) (Mondal et al., 2003; Mondal and Gupta, 2006; Mondal et al., 2006; Gautam et al., 2012).

Finally, affinity based separations rest upon the molecular recognition of a ligand by a protein/enzyme. While affinity chromatography was initially exploited in vivo biological relationship that line was crossed quite some time back, when textile dyes were introduced as affinity ligands. Diverse types of affinity ligands like peptides, aptamers and other synthetic ligands show the promiscuity of a protein in binding. Much of our thinking so far in this area has been rooted in enzyme catalysis in the aqueous buffers. Biocatalysis in low water media shows that the concept of medium engineering in biocatalysis perhaps can be extended to the bioseparation area. Quite some time back, the work from Klibanov's lab showed the possibility of carrying out protein separation in low water media (Chang et al., 1991). Ringe's provocative discussion on: "What is a binding site on a protein?" needs more attention (Ringe, 1995).

\section{Soluble Crosslinked Enzymes and Hetero- conjugates}

The cross-linking of bovine pancreatic RNase A was the first attempt at examining the structural and functional consequences of crosslinking a protein intramolecularly (Hartman and Wold, 1967). It also introduced the use of bis-imido esters in protein crosslinking. The chemical derivative was soluble in aqueous buffer and thus no chemical aggregation was involved. It had improved thermal stability and retained excellent RNase A activity. Ensuing decades saw a flurry of extensive applications, which are described at a number of places (Wold, 1972; Wong, 1991).

It was shown that a cross-linked trypsin by dimethyl adipimidate and dimethyl suberimidate (bisimido esters) showed significantly decreased autolysis at $40^{\circ} \mathrm{C}$ (Rajput and Gupta, 1988a). The two bifunctional reagents were also employed for crosslinking of $\beta$-galactosidase. This enzyme has many biotechnological applications (Huber et al., 1994). Lactose intolerance is a metabolic disorder prevalent in different ethnic groups. For such people, low lactose milk obtained by the hydrolysis of lactose present in milk has been an important product impacting their quality of life. Also, the whey obtained during cheese production retains all the lactose and its discharge into water bodies is problematic. It has high BOD value. The enzymatic hydrolysis of whey gives component sugars, which in turn can be exploited for obtaining value added products including bioethanol. These are mature technologies developed by multinationals (Gekas and Lopez-Leiva, 1985; Kosaric and Asher, 1985). The cross-linked $\beta$-galactosidase retained $80 \%$ of its activity. The cross-linked enzyme was a better catalyst for the hydrolysis of lactose in both milk and whey (Khare and Gupta, 1987). $\beta$-galactosidase can also be used for the reverse 
hydrolysis in organic synthesis (Majumder et al., 2007).

These soluble enzymes are not easy to recover and re-use. However, the above soluble cross-linked preparations of $\beta$-galactosidase entrapped in polyacrylamide gels improved its thermostability even further and converted it into a re-usable biocatalyst (Khare and Gupta, 1988a).

More remarkable was the effect of introducing just one cross-link into the lectin concanavalin A (Kamra and Gupta, 1988). While lectins are now widely recognized as useful reagents in biology, Con A has proved so useful that a book devoted solely to it was available long ago (Bittiger and Schnebli, 1976). Cross-linking of Con A yielded multiple products. One of these was an intramolecularly cross-linked Con A, which had just one crosslink and retained $98 \%$ of its biological activity. As this cross-linking between Lys 135 and Lys 138 was part of the disordered region between 131-168 amino acids, the cross-linked Con A showed high thermostability even at $70^{\circ} \mathrm{C}$, atleast upto $>2$ hours, a temperature at which most of the activity of the native Con A is lost within 30 minutes (Kamra and Gupta, 1988).

Soluble hetero-conjugates of proteins can also be obtained by judicious intermolecular cross-linking of the component proteins. ELISA reagents are the best known examples and are bioconjugates of antigens/antibodies with an enzyme (alkaline phosphatise and peroxidase are used more often) (Stites and Terr, 1991). This approach has also been used to develop multi-functional proteins or for modelling metabolic segments (Bulow, 1993). In the early phase of development of this approach, a trypsinchymotrypsin conjugate was prepared to design a proteolytic biocatalyst, which synergized the activities of trypsin and chymotrypsin (Rajput and Gupta, 1988b). N-succinimidyl pyridyl dithiopropionate (SPDP) turned out to be the best cross-linking reagent out of the many, which were tried.

A Con A $\beta$-galactosidase conjugate could also be prepared using glutaraldehyde as the cross-linking reagent (Khare and Gupta, 1988b). This conjugate was used for bioaffinity immobilization of $\beta$ - galactosidase by exploiting the recognition of dextran beads by Con A. Bioaffinity immobilization is still used as a reversible method of immobilization. It allows the "on-site" immobilization. It is especially useful in cases, where, the matrix costs more than the enzyme (e.g.: as in the case with several enzymes used in food processing industry) and, additionally, it is very economical to remove inactivated enzyme from the matrix and 'freshen up' the biocatalyst with the new lot of active bioconjugates (Gupta and Mattiasson, 1992).

Bio-affinity immobilization is also useful as it allows deposition of multi-layers on a small surface. In one case, pectinases (an enzyme useful in fruit juice processing) could be layered onto a sephadex bead by forming alternate layers of the lectin and the glycoprotein pectinases (Sardar and Gupta, 2005). In yet another application, a horse radish peroxidase immobilized by bioaffinity layering was shown to be useful for treatment of phenolic waste waters (Dalal and Gupta, 2007).

\section{Enzyme Aggregates in Biocatalysis and Biosensor Designs}

Extensive cross-linking of enzyme molecules in solution leads to their forming insoluble enzyme aggregates. While some intramolecular cross-linking may take place, formation of intermolecular cross-links between enzyme molecules is largely responsible for this aggregation. While, in principle, any bifunctional reagent can be used, glutaraldehyde has been most frequently employed. Glutaraldehyde is a most efficient cross-linking reagent when no subtle alteration in protein structure is desired.

Broun (1997) called such aggregates as "chemically aggregated enzymes" and described these aggregates for all five classes of enzymes. These gel-like aggregates can be converted into sheets or coating and thus can be used in the design of enzyme electrodes or other kinds of biosensors. Any condition which prevents inactivation/denaturation of the enzymes during chemical modification reactions (Means and Feeney, 1990), also favours retention of activity in these insoluble aggregates. This includes low temperature and protection of the active site by a 
substrate analog/one of the substrates/co-enzyme. One interesting option suggested by Broun (1997) was to incorporate proteic feeder (an inert protein like BSA) to promote cross-linking if the enzyme did not have enough reactive amino groups in the protein.

These methods were used to obtain chemical aggregates of $\beta$-galactosidase (Khare and Gupta, 1987). The improved thermal stability of the enzyme at $55^{\circ} \mathrm{C}$ was reflected in its better performance in the hydrolysis of milk lactose. Immobilized $\beta$ galactosidases (also called lactases) were one of the early immobilized enzymes used at the industrial level. A significant $\%$ of the population of adults in various countries is lactose intolerant. Hence, many developed countries produce low lactose milk and its products for these consumers.

Chemical aggregates represent what is sometimes referred to as carrier-free immobilization (Cao et al., 2003; Sheldon, 2007). The insoluble enzyme has no carrier (except possibly BSA added as a proteic feeder). In immobilized enzymes (conventional ones with matrices/carriers), the matrix occupies larger volume than just the linked/attached enzyme. Hence, chemical aggregates offer a possibility of reducing bioreactor size and have extremely high volumetric activity (Broun, 1997).

\section{Cross-linked Enzyme Aggregates (CLEAs)}

Much later, a patented technology called cross-linked enzyme aggregates (CLEA) was developed (Schoevaart et al., 2004; Sheldon et al., 2005; Sheldon, 2007). The difference between the methods of preparations of CLEAs and the earlier described chemically aggregated enzymes is rather subtle. During CLEA formation, the enzyme is first precipitated and then glutaraldehyde is added to crosslink the protein extensively to insolubilize it. It has been claimed that CLEAs are much better in performance as compared to the chemically crosslinked enzymes (Schoevaart et al., 2004; Sheldon et $a l ., 2005)$. While the latter appeared to be more gellike, CLEAs are somewhat easier to handle and transfer (Cao et al., 2003; Sheldon, 2007).
Both, chemically aggregated enzymes (CAEs) and CLEAs, just like other immobilized preparations can be used in aqueous-organic co-solvent mixtures and even low water containing organic solvents/ionic liquids. Such media offer many advantages. Hydrolases can be used to carry out reverse hydrolysis. Change of media allows one to optimize region-selectivity and stereo-selectivity during biotransformation (Wu et al., 1991). One key constraint has been that enzymes show much lower catalytic power in organic solvents than displayed in aqueous buffers. There are many reasons and fairly good discussions on this are available in a few reports (Lee and Dordick, 2002; Hudson et al., 2005; Roy and Gupta, 2004a; Roy et al., 2004). Many efforts have been made to improve the catalytic activity of enzymes in especially low water media (Ljungar et al., 1993; Okahata et al., 1997; Adlercreutz, 2013; Solanki et al., 2012; Khmelnitsky et al., 1994; Partridge et al., 1998; Majumder et al., 2008; Roy and Gupta, 2004b; Kreiner et al., 2001; Shah et al., 2008). CLEAs are regarded as such high activity preparations. Unfortunately, the comparative data on various such high activity preparations is meagre. It has been observed that simple precipitates, obtained during CLEA preparation (without the subsequent step of adding glutaraldehyde) sometimes show just as much of catalytic efficiency as CLEAs (Shah and Gupta, 2007a)!

The effect of introducing cross-links during formation of CLEAs introduces rigidity in the protein molecules. Over-rigidity has (especially in low water media) deleterious consequences. A good illustration of this is the observation that urea denatured subtilisin is, in fact, a far more efficient biocatalyst than the native subtilisin in nearly anhydrous organic solvents (Guo and Clark, 2001; Mukherjee et al., 2015). In fact, CLEAs obtained by varying the extent of crosslinking have different thermal stabilities, catalytic efficiencies and enantio-selectivities (Majumder et al., 2008). More extensive discussion on various approaches to design of CLEAs and their applications in biocatalysis can be found elsewhere (Lopez Serrano et al., 2002; Sheldon et al., 2005; Shah et al., 2006; Sheldon, 2007; Gupta and Raghava, 2011). However, mention should be made here of two different choices 
about cross-linking reagents. In some cases, dextran polyaldehyde has been found to be a milder cross linker than glutaraldehyde. It is believed, that this bifunctional reagent does not diffuse in the interior of the protein molecule because of its big size and crosslinking is limited to the involvement of surface amino groups (Mateo et al., 2004). In the second approach, chitosan has been inserted with the enzyme molecule using carbodiimide coupling of the amino groups on chitosan and the carboxyl groups on the enzyme (Arsenault et al., 2011).

\section{Catalytic Promiscuity Offers Under-exploited Opportunity and Challenge}

Enzymes are not all that specific! We have known for a long time about their broad specificity (Gupta et al., 2011). Catalytic promiscuity goes beyond that. Hydrolases can catalyse the formation of C-C bonds (Hult and Berglund, 2007; Khersonsky and Tawfik, 2010; Busto et al., 2010; Kapoor et al., 2014; Arora et al., 2014a). Such promiscuous behaviour is possible for wild enzymes (accidental promiscuity) but can also be induced or at least improved by protein engineering/ directed evolution (Khersonsky and Tawfik, 2010). This kind of catalysis is possible in both aqueous buffers as well as in non-aqueous solvents (Liu et al., 2008; Lou et al., 2008; Arora et al., 2014b) (Figs. 1 and 2). This also makes it possible to synthesize a
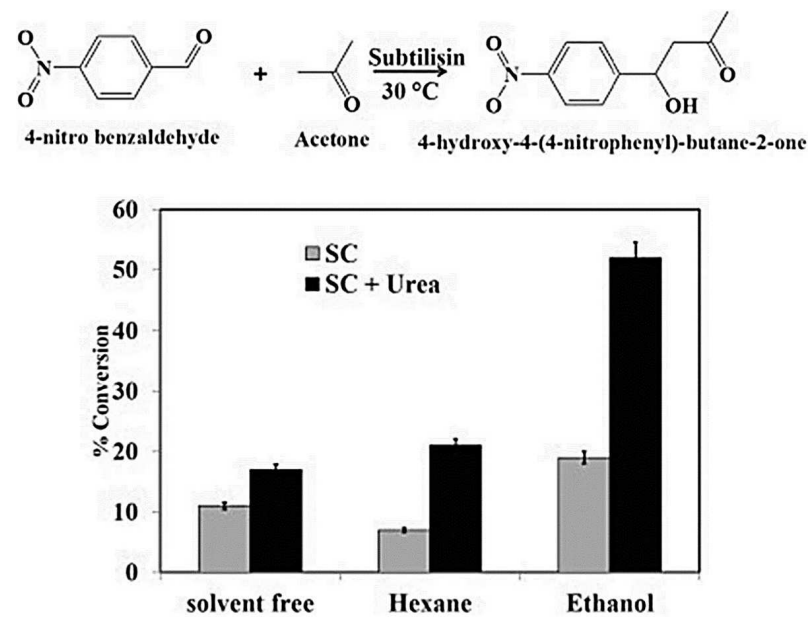

Fig. 1: Aldol condensation reaction catalysed by subtilisin (SC) and urea treated subtilisin (SC+urea) carried out in different solvents. (Reproduced from Mukherjee et al. 2015 with permission from Elsevier)

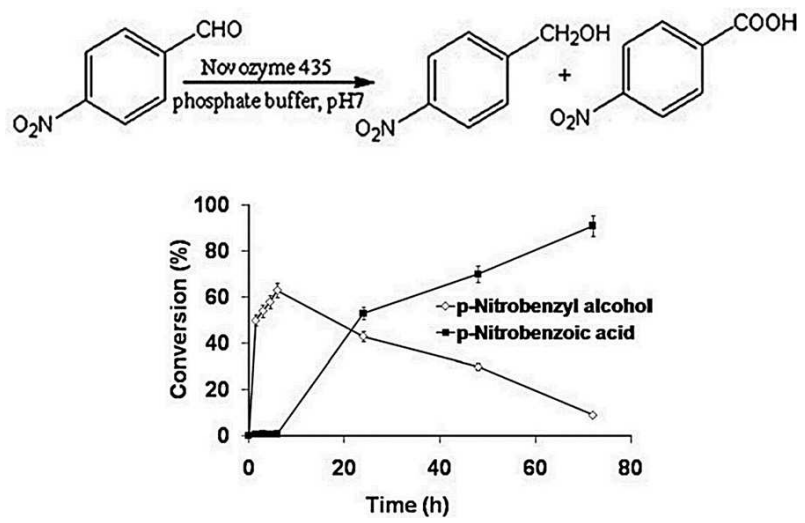

Fig. 2: Cannizzaro-type reaction of $p$-nitrobenzaldehyde catalyzed by Novozyme 435 in aqueous buffer. (Reproduced from Arora et al. 2014(a) with permission from Elsevier)

library of molecules with diverse and unexpected structures (Majumder and Gupta, 2014).

It seems that the promiscuous behaviour is an integral part of evolutionary designs of proteins (Soskine and Tawfik, 2010; Goldsmith and Tawfik, 2012; Skolnick and Gao, 2013). This area is providing a great insight into how enzyme activities evolved. More important, it makes enzymes even more versatile as biocatalysts.

\section{Applied Bio-catalysis and "Make in India" Program}

A successful chemical process based upon an enzyme requires (a) being able to source enzyme (upstream and downstream) (b) to be able to optimize the "way enzyme is used" (biocatalyst engineering and medium engineering) to result in a commercially successful process.

India has a rich tradition in both microbiology and enzymology (Table 2). These two disciplines are relevant to developing skill sets for (a) and (b) steps mentioned above. Unlike some other countries, lot of investment was made at the right time in developing manpower skilled in rDNA technology. However, India still has to import almost all diagnostic enzymes (including one for biosensor designs) and majority of the enzymes needed for industrial enzymology. There must be something, which we are not doing right in harvesting the benefits of our old strengths and recent 
Table 2: Indian Strength in Applied Biocatalysis

\begin{tabular}{ll}
\hline Protein & Comments \\
\hline Upstream Processes & $\begin{array}{l}\text { Great strength in isolating and characterizing micro organisms as a source of enzymes (Roy } \text { et al., 2001; } \\
\text { Satyanarayana and Kunze 2009; Sharma } \text { et al., 2012; Verma } \text { et al., 2013) }\end{array}$ \\
Downstream Processes & $\begin{array}{l}\text { Apart from very few groups, Indian groups still use either multistep procedures or affinity tag based kits } \\
\text { which are difficult to scale up. (Manjunath } \text { et al., 1983; Kumar and Bhalla 2004; Kale and Lali 2011) }\end{array}$ \\
Immobilization & $\begin{array}{l}\text { Some of the very original work came from the AMU group. It is also nice to see Indian groups contributing } \\
\text { to CLEA design. (Saleemuddin and Husain 1991; Saleemuddin 1999; Talekar } \text { et al., 2012) }\end{array}$ \\
Use in low water media & $\begin{array}{l}\text { Very few groups work in this area. Parmar till recently had a group. (Parmar } \text { et al., 1999; Banoth } \text { et al., } \\
\text { 2009; Amrutkar } \text { et al., 2013) }\end{array}$ \\
Expression, Engineering & $\begin{array}{l}\text { There are many groups who work with protein engineering; not many with stabilization as an aim. Not } \\
\text { and Refolding }\end{array}$ \\
much original work is happening in the protein refolding area. (Kulothungan et al., 2009; Saha et al., 2011; \\
Sowdhamini and Balaram 1993) \\
Stability
\end{tabular}

investments. Few possible reasons (perhaps worth pondering) are:

- We tend to overdo things (Gupta, 2012). We need to retain what is good and not throw away the baby with bath water. Our syllabi follow books written by foreigners, that are rightly or wrongly more in tune with what is needed in those countries. For example, two text books in biochemistry (Berg et al., 2002; Nelson and Cox, 2009) often followed in our country (and syllabi normally are based upon "available texts"!) have very little enzymology in their current editions. Our current crop of students are reasonably good in molecular biology (can use kits as advised by vendors quite well) but know very little of enzymology. It is known that scientists who work with method development/process development will never get to publish in high impact factor journals. Few years back, there was a discussion published in Nature wherein Professor Southern (discoverer of Southern Blotting) remarked that not everybody is lucky enough to be recognized for developing a method. We seem to be sending a strong message through multiple channels not to work on method developments. Unfortunately, it is the work of that nature, which hones your skills in the areas like applied biocatalysis.

- We tend to overlook that "research" and "development" follow different approaches. In the former, you need to follow a logical framework and explain how and why each step worked. In developmental work, it is alright to stumble upon an observation and/or a lead and not worry too much about how and why of it. Later on, somebody can figure that out and that can lead to a better process/method. When Klibanov's group showed that enzymes work in low water enzymology, in reality very little of correct mechanistic details were known. The scientific world showed great judgement in recognizing the usefulness of the technology and only in recent years, we are beginning to understand many phenomenological and mechanistic aspects (Gupta, 1992; Halling, 1994; Carrea and Riva, 2000; Hudson et al., 2005). 
- We need to include many areas like non-aqueous enzymology, enzyme promiscuity and moonlighting proteins in our syllabi and encourage people to work in these areas. The first one offers an opportunity for biocatalyst-based synthesis of industrial and drug intermediates, agrochemicals and biosurfactants (Gupta, 1992; Halling, 1994; Carrea and Riva, 2000; Hudson et al., 2005). The second one is connected to developing antibiotic resistance (Green et al., 2010; Kim et al., 2013) and the third one is concerned with the next generation drug designs (Copley, 2003; Jeffery, 2009).

\section{The Issue of Economics}

The industry is naturally concerned about whether a proposed idea is economically or commercially feasible. Indian industry, actually, is obsessed with it when it is an "Indian idea". Unfortunately, that may be our mindset as similar bias is there among our academic people while looking at another Indian's funding proposal/submitted article. In a lighter vein, may be there should be an international program where good Indian ideas are routed through a foreign outfit for Indian industry to consider! Few specific observations are:

One cannot work out the economics of a process unless optimization is complete. It is known that, all over the world, biodiesel when sold relies upon tax breaks. That is so, even when a chemical process is used, which is how biodiesel is mostly made at present. Everybody agrees that enzyme based process is the future. China has a plant running on enzyme based route and another has been set up in USA recently (Fjerbaek et al., 2009; www.researchtriangle.org). Enzyme based route, is of course more costly than the chemical route. It is necessary to deal with the myths about costly enzymes and economic considerations preventing adoption of more sustainable approaches in Indian chemical industries and biofuel programs. 6-aminopenicillinic acid is an intermediate obtained by industries in the world generally by an enzyme called penicillin acylase. The process involves the hydrolysis of natural penicillins. To quote "...the cost contributions of the biocatalysts to the final sales price could easily be less than $1 \%$ " (Cheetham, 2000). Similar estimates are available for cost of enzymes in producing dextrins from starch, glucose from dextrins, high fructose corn syrup, invert sugars and low lactose products (Cheetham, 2000).

Finally below is a list of some results in applied biocatalysis which may have been good "leads" to processes which can aspire to be a part of the "Make in India" or "Developed in India" program.

\section{(a) Biodiesel}

A recent review pointed out that an enzyme based route established in India is globally the fastest enzymatic process ever reported for biodiesel preparation (Fjerbaek et al., 2009). While Jatropha as a source of oil has not turned out to be a success story, Japan has been using kitchen waste as a source of oil for biodiesel production! We have published some work recently on how to exploit spent coffee grounds as a source of oil for biodiesel (Fig. 3). A 2009 US estimate showed that spent coffee grounds can add 340 million gallons of biodiesel to the worlds fuel supply (www.acs.org). The biodiesel production elsewhere had to overcome food vs. fuel debate. It is more economical to learn from the mistakes of other countries to enable "Make in India" program to succeed.

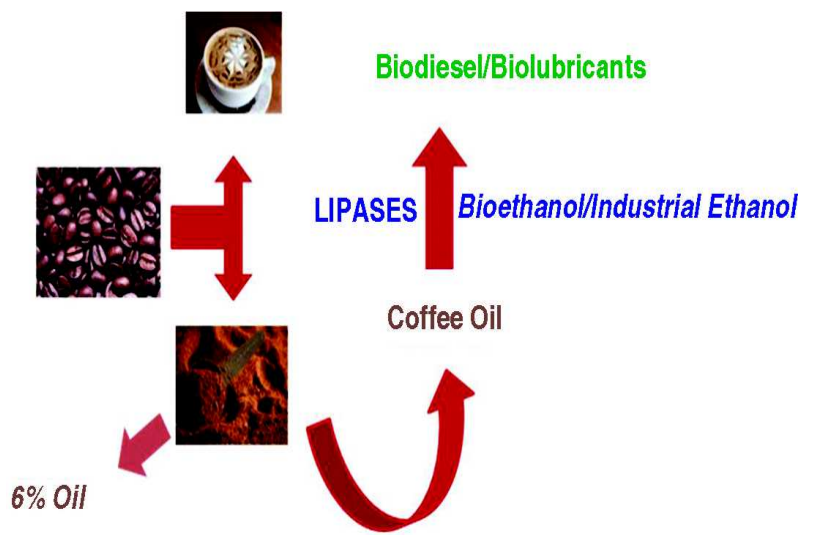

Fig. 3: Enzyme-based route for the valorization of coffee waste to produce biodiesel. (Reproduced from Banerjee et al. 2013 with permission from Chemistry Central) 


\section{(b) Enzyme Production}

Bulk of the production cost of enzymes comes from the cost involved at the downstream processing step.

(i) Many years back, it was shown that Con Abound to DEAE-cellulose constitute a versatile affinity media (Kamra and Gupta, 1987). The reason was that, affinity media combined the affinity of Con A towards some glycoproteins with the ion-exchange properties of DEAE-cellulose. More recently, an expensive range of separation media under multimodal chromatography has become available (www.gelifesciences.com). The separation media is especially shown as useful for the purification of monoclonals. Here again, the principle is that the separation media binds proteins with more than one kind of interactions.

Actually, as a well known book (among old school) on protein purification points out, no separation media can ever completely bind a protein with just one type of interaction (Scopes, 1994)! The discovery of a fairly powerful technique called hydrophobic interaction chromatography (HIC) was accidental while designing affinity media for alcohol dehydrogenases. The enzyme bound to the linker $-\left(\mathrm{CH}_{2}-\mathrm{CH}_{2}\right)_{-}$chain instead (Burgess and Deutscher, 2009).

The lesson is two-fold. Firstly, we need to showcase our findings better but we do have a huge problem with the "Indian crab syndrome" among Indian peers. Secondly, new "ultratech" discoveries arise out of observations which we tend to dismiss as old hat!

To underline the above, an example may be mentioned. Expanded bed chromatography was heralded as a new unit process for protein bioseparation in several decades (Chase and Draeger, 1992; McCreath et al., 1994; Garg et al., 1996; Owen and Chase, 1997). It utilizes streamline $^{\mathrm{TM}}$ range of media which form a "stable fluidized bed" called Expanded Bed (Chang and Chase, 1996; Karau et al., 1997).
It has been shown that simple alginate beads can form stable fluidized beds and illustrates its applications in a number of cases (Roy et al., 2001; Sharma et al., 2001; Roy and Gupta, 2002 b,c; Roy et al., 2005). Alginate is an inexpensive polysaccharide of marine source which is used in food processing, whole cell immobilization and as scaffolds in tissue engineering (Skaugrud $e t$ al., 2013).

(ii) MLFTPP: A new unit process called macroaffinity ligand facilitated three phase partitioning (MLFTPP) shares the virtue of being directly able to deal with crude suspensions as feed with the expanded bed chromatography. It also has been shown to be quite helpful in both protein purification and protein refolding (Fig. 4). The technique is inexpensive and does not require any costly equipment. This unit process was

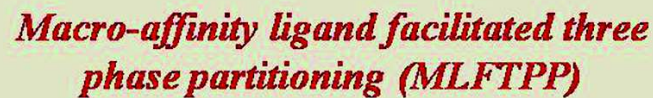
phase partitioning (MLFTPP)

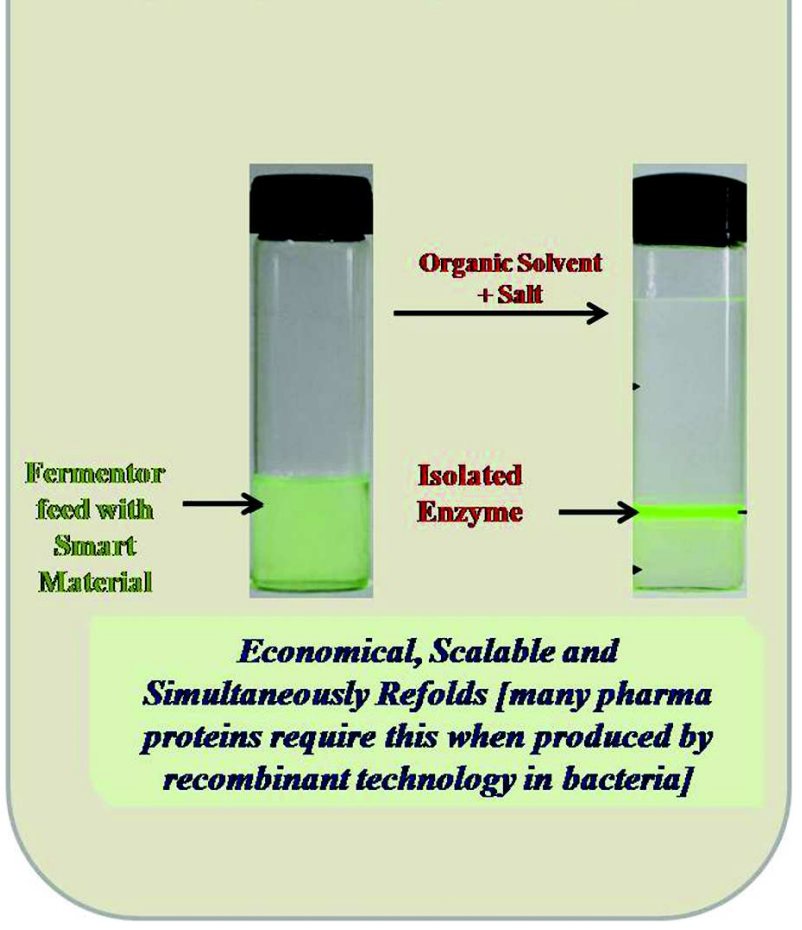

Fig. 4: MLFTPP as a economic and scalable method to purify and refold proteins 
described as a process yet to attain industrial maturity (Przybycien et al., 2004).

\section{(c) Enzymology Beyond Aqueous Buffers}

Classical enzymology consisted of using enzymes in aqueous buffers. Most of the early industrial enzymology was based upon enzyme action in water rich media. All those are excellent applications of enzymology and continue to be part of the current biotechnological practices.

The quest to use inexpensive hydrolases for synthesis has a long history. Joseph Fruton, who wrote the first text book of biochemistry (Fruton and Simmonds, 1958), has reported many efforts to use pepsin for peptide synthesis (Fruton, 1970; Sachdev and Fruton, 1975; Fruton, 1976, 1982, 1983). The strategy was to use the law of mass action to shift the equilibrium towards synthesis by using concentrated solutions of the amino acids. In the late 1980 's, a series of papers showed that lyophilized powders of hydrolases could carry out synthesis very effectively in nearly anhydrous organic solvents (Zaks and Klibanov, 1984, 1988). There are several advantages associated with this approach. When hydrolases are used for the organic synthesis in such media, varying solvents could be used to change/ control enantio-selectivity in the reactions. As chemical industries anyway use organic solvents as the reaction medium for most of the synthesis, use of enzymes does not necessitate major changes in the plant designs.

One major disadvantage of this approach which was soon noticed, was that catalytic efficiencies of the enzymes were much less in organic media and hence, larger amount of enzymes needed to be used.

Many efforts have been made globally to overcome this constraint. Some Indian findings are briefly listed below.

- Enzymes have to be in dry state. Presence of excess water (>5\% v/v generally) initiates competing hydrolytic reactions. It has been found that precipitation with water miscible organic solvents works better than freeze drying for obtaining a more active enzyme preparation
(Roy and Gupta, 2004b; Solanki and Gupta, 2008; Majumder and Gupta, 2011; Solanki et al., 2012).

- CLEAs developed by Sheldon's group (see the earlier section for the discussion on CLEAs) work well in low water as well. CLEAs anyway require precipitation as a first step. Sometime CLEAs work better (Majumder et al., 2008; Shah et al., 2006) while in some other reactions simple precipitates which we called "Enzyme Precipitated and Rinsed in Organic Solvents" (EPROS), work better than even CLEAs (Shah and Gupta, 2007a).

- In many cases, we find that enzymes after being subjected to Three Phase Partitioning (TPP) have significantly higher activities in neat organic solvents (Singh et al., 2001; Roy et al., 2004; Rather et al., 2012). TPP was also able to refold denatured proteins (Raghava et al., 2008) (Fig. 5 and Table 3). (i)
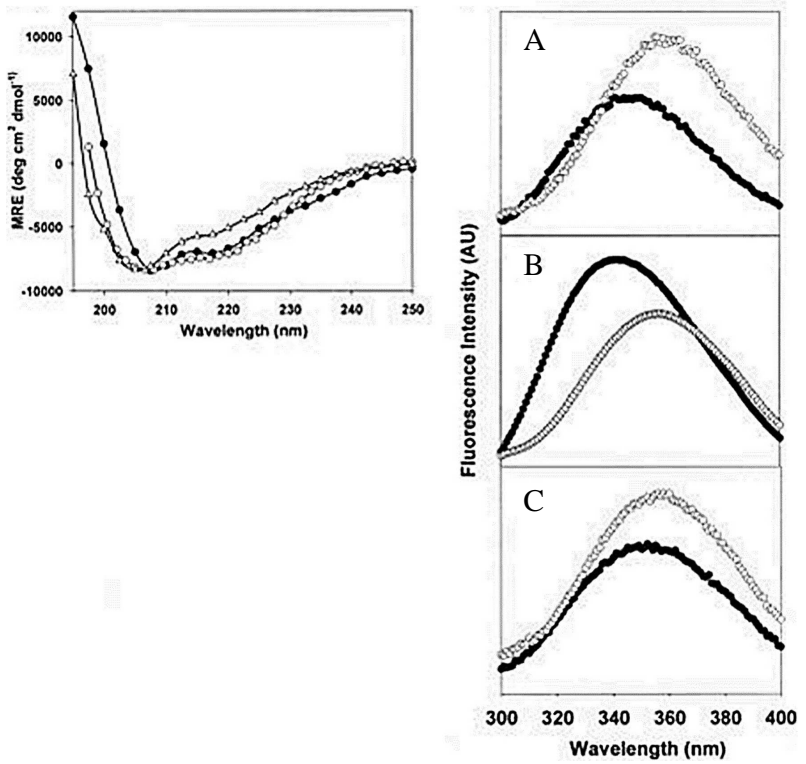

Fig. 5: (i) Far-UV CD spectra for CcdB proteins in $10 \mathrm{mM}$ Tris, pH 7.5: WT-CcdB (•), CcdB-F17P (o), and CcdBM97K ( $\Delta$ ). (ii) Fluorescence emission spectra (AU, arbitrary units) from 300 to $400 \mathrm{~nm}$ for CcdB proteins in $10 \mathrm{mM}$ Tris, $\mathrm{pH} \mathrm{7.5,} \mathrm{using} \mathrm{excitation} \mathrm{and} \mathrm{emission}$ slit widths of $2 \mathrm{~nm}$ and $5 \mathrm{~nm}$, respectively. Protein samples at a concentration of $\sim 1$ iM were incubated either in buffer $(\cdot)$ or in buffer containing $5 \mathrm{M} \mathrm{GdmCl}$ $\left({ }^{\circ}\right)$ for $3 \mathrm{~h}$ before spectral acquisition. (A) WT-CcdB, $(B)$ CcdB-F17P, and $(C)$ CcdB-M97K (Reproduced from Raghava et al. 2008 with permission from Wiley-VCH) 
Table 3: Comparison of results obtained by TPP with conventional methods (Reproduced from Raghava et al., 2008 with permission from Wiley $\mathrm{VCH}$ )

\begin{tabular}{|c|c|c|c|}
\hline S.No. & Protein & $\begin{array}{l}\text { Refolding by } \\
\text { TPP method }\end{array}$ & $\begin{array}{l}\text { Refolding by } \\
\text { conventional method }\end{array}$ \\
\hline I & $\begin{array}{l}\text { RNase A } \\
\text { Total time }^{\mathrm{a}} \\
\text { Yield }^{\mathrm{b}}\end{array}$ & $\begin{array}{l}36 \mathrm{~h} \\
40-45\end{array}$ & $\begin{array}{l}3-4 d \\
4-8^{c}\end{array}$ \\
\hline II & $\begin{array}{l}\text { CcdB-F17P } \\
\text { Total time }^{\mathrm{a}} \\
\text { Yield }^{\mathrm{b}}\end{array}$ & $\begin{array}{l}15 \mathrm{~h} \\
30-32\end{array}$ & $\begin{array}{l}\text { Not refoldable } \\
-\end{array}$ \\
\hline III & $\begin{array}{l}\text { CcdB-M97K } \\
\text { Total time }^{\mathrm{a}} \\
\text { Yield }^{\mathrm{b}}\end{array}$ & $\begin{array}{l}15 \mathrm{~h} \\
30-35\end{array}$ & $\begin{array}{l}\text { Not refoldable } \\
-\end{array}$ \\
\hline IV & $\begin{array}{l}\text { MBP224D } \\
\text { Total time }^{\mathrm{a}} \\
\text { Yield }^{\mathrm{b}}\end{array}$ & $\begin{array}{l}15 \mathrm{~h} \\
38-43\end{array}$ & $\begin{array}{l}\text { Not refoldable } \\
-\end{array}$ \\
\hline V & $\begin{array}{l}\text { MBP264D } \\
\text { Total time }^{\mathrm{a}} \\
\text { Yield }^{\mathrm{b}}\end{array}$ & $\begin{array}{l}15 \mathrm{~h} \\
38-43\end{array}$ & $\begin{array}{l}\text { Not refoldable } \\
-\end{array}$ \\
\hline VI & $\begin{array}{l}\text { Trx mutant } \\
\text { Total time } \\
\text { Yield }^{\mathrm{b}}\end{array}$ & $\begin{array}{l}15 \mathrm{~h} \\
60-62\end{array}$ & $\begin{array}{l}\text { Not refoldable } \\
-\end{array}$ \\
\hline VII & $\begin{array}{l}\text { CD4D12 } \\
\text { Total time }^{\mathrm{a}} \\
\text { Yield }^{\mathrm{b}}\end{array}$ & $\begin{array}{l}17 \mathrm{~h} \\
3-5\end{array}$ & $\begin{array}{l}24 \mathrm{~h} \\
1\end{array}$ \\
\hline VIII & $\begin{array}{l}\text { DPTP10D } \\
\text { Total time }^{\mathrm{d}} \\
\text { Yield }^{\mathrm{b}}\end{array}$ & $\begin{array}{l}15 \mathrm{~h} \\
18\end{array}$ & $\begin{array}{l}\text { Refoldable } \\
1-2\end{array}$ \\
\hline IX & $\begin{array}{l}\text { DPTP52F } \\
\text { Total time }^{\mathrm{a}} \\
\text { Yield }^{\mathrm{b}}\end{array}$ & $\begin{array}{l}15 \mathrm{~h} \\
30\end{array}$ & $\begin{array}{l}\text { Not refoldable } \\
-\end{array}$ \\
\hline$X$ & $\begin{array}{l}\text { DPTP69D } \\
\text { Total time }^{\mathrm{a}} \\
\text { Yield }^{\mathrm{b}}\end{array}$ & $\begin{array}{l}15 \mathrm{~h} \\
38\end{array}$ & $\begin{array}{l}\text { Not refoldable } \\
-\end{array}$ \\
\hline XI & $\begin{array}{l}\text { DLAR } \\
\text { Total time } \\
\text { Yield }^{\mathrm{b}}\end{array}$ & $\begin{array}{l}15 \mathrm{~h} \\
42\end{array}$ & $\begin{array}{l}\text { Not refoldable } \\
-\end{array}$ \\
\hline XII & $\begin{array}{l}\text { DPTP99A } \\
\text { Total time } \\
\text { Yield }^{\mathrm{b}}\end{array}$ & $\begin{array}{l}15 \mathrm{~h} \\
40\end{array}$ & Not refoldable \\
\hline
\end{tabular}

${ }^{\mathrm{a}}$ For purification and refolding; ${ }^{\mathrm{b}}$ Method for calculating yield $\left(\mathrm{mgL}^{-1}\right)$ of culture): ([Total purified protein $(\mathrm{mg}) \mathrm{x}$ fraction of pure protein $] \div$ culture volume $(\mathrm{mL}) \times 1000$. ${ }^{\text {F Following the }}$ method of refolding "without TPP" mentioned in Materials and Methods section, yields of 5-15 $\mathrm{mgL}^{-1}$ are obtained; del Cardayré et al. (1995) report yields as high as $50 \mathrm{mgL}^{-1}$; a more recent paper by a different group (Tanimizu et al. 2002) report yields of about $5 \mathrm{mgL}^{-1}$; ${ }^{\mathrm{d}}$ No activity was obtained in this PTP
- Protein Coated Microcrystals (PCMC) is a patented technology developed in U.K. (Kreiner et al., 2001). In this a mixture of an enzyme and a low molecular weight substance (salt, sugar or amino acid) is precipitated by an organic solvent. The low molecular weight substance rapidly forms microcrystals, the slower precipitation of the proteins results in proteins coating over the microcrystals. PCMC has been described as a highly active biocatalyst design for low water media. The results from our laboratory also agree with that. It was also shown that Cross-Linked Protein Coated Microcrystals (CLPCMC) in some cases
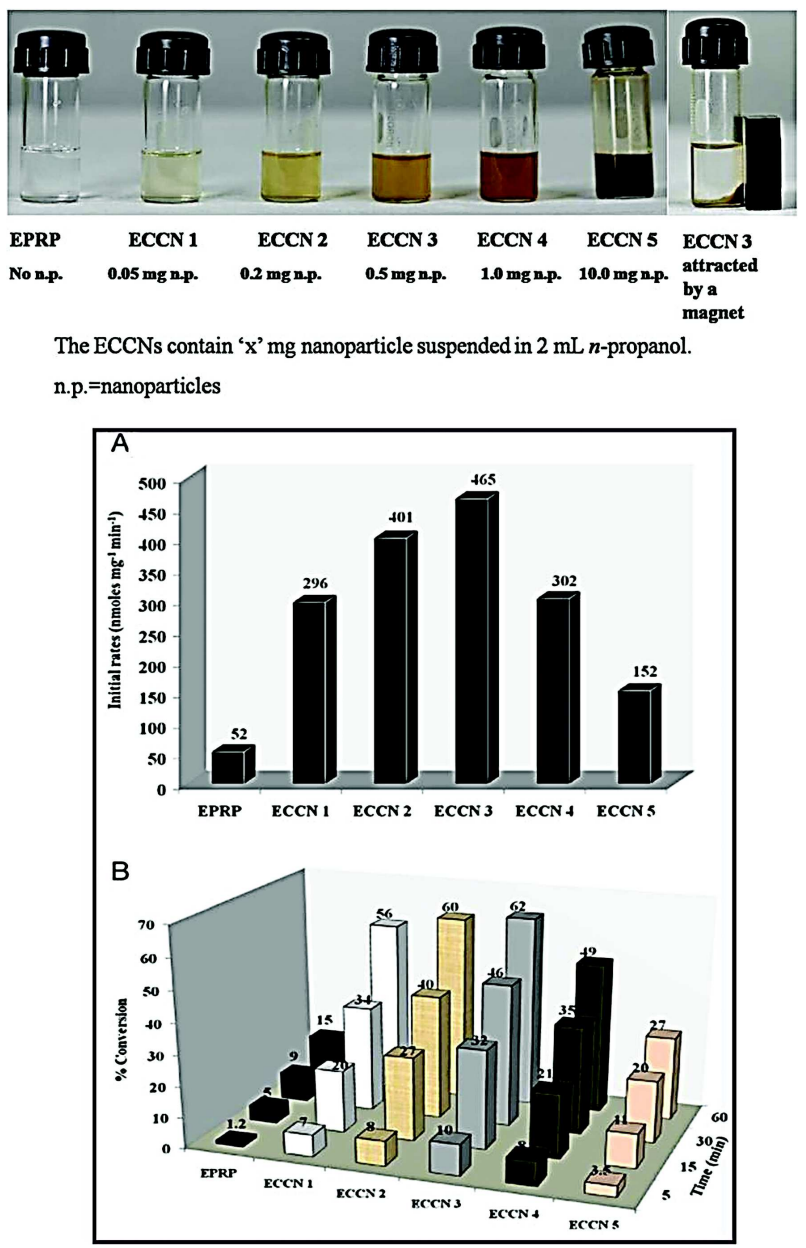

Fig. 6: Enzyme coated clusters of nanoparticles as a high activity biocatalyst design. A) Initial rates for the trans-esterification of $\mathrm{N}$-acetyl-L-phenylalanine ethyl ester and $n$-propanol in $n$-hexane (B) Conversions for the same reaction. (Reproduced from Mukherjee and Gupta 2012 with permission from Chemistry Central Journal) 
worked better than even PCMC. An Indian patent application has been filed for this biocatalyst design (Shah et al., 2008).

- Enzymes bound to super-paramagnetic $\mathrm{Fe}_{3} \mathrm{O}_{4}$ nanoparticles also show highly improved synthetic activity in organic solvents (Solanki and Gupta, 2011).

- Alpha chymotrypsin engulfing clusters of the same nanoparticles show high synthetic activity (Mukherjee and Gupta, 2012) (Fig. 6).

Reverse micelles and ionic liquids represent other low water media (Shah and Gupta 2007a, b; Orlich and Schomäcker, 2002). Some solvents like ionic liquids, ethyl lactate, cyclopentylmethylether and glycerol are called green solvents (Watanabe et al., 2007; Aparicio and Alcalde, 2009; Diaz-Alvarez et $a l .$, 2014). Such green media offer an opportunity of more sustainable designs for the biocatalytic processes in low water media for organic synthesis.

\section{Conclusions}

Biotechnology is expected to play an ever increasing role in development of sustainable chemical processes. This promise is largely based upon (a) sourcing raw materials from renewable resources (b) replacing chemical catalysts with biocatalysts. Applied biocatalysis plays an important role in all this. Both Japan and China (to name two countries) have strong base in applied biocatalysis.

If 'Make in India' program has to cover biotechnology, we cannot afford not to re-establish and strengthen our emphasis on applied biocatalysis.

\section{References}

Adlercreutz P (2013) Immobilisation and application of lipases in organic media Chem Soc Rev 42 6406-6436

Adlercreutz P, Larsson K and Matiasson B (1988) Studies of Some Oxidoreductases Solubilized in Reverse Micelles Annl New York Acad Sci 542 270-273

Amrutkar S M, Banoth L and Banerjee U C (2013) One-pot synthesis of (R)-1-(1-naphthyl) ethanol by stereoinversion using Candida parapsilosis Tetrahedron Lett 54 32743277
Finally, not all scientists are good salesmen. Some are literally invisible as they are not part of decision making process in India. Nevertheless, the ideas and research leads are important. We need to rethink about how to nurture those.

\section{Acknowledgements}

M N Gupta will like to acknowledge CSIR, DST and DBT for supporting the research described in the review. Thanks to SAREC (Sweden) support which made it possible to acquire the first UV-visible spectrophotoimeter after 15 years of quest for that. MNG will also like to thank many mentors. Professor Paul J Vithyathil at IISc, Bangalore who taught him what enzymes were all about? Professor Finn Wold (University of Minnesota, USA) who furthered this awareness and also taught protein cross-linking. Professor A M Klibanov (MIT, USA) who provided the exposure to the art of using enzymes in organic solvents. Professor Bo Mattiasson (University of Lund, Sweden), a contemporary but miles ahead in Science, who taught this author what biotechnology is all about. MNG will also like to thank Dr. Rao Aiyagiri (the then SERC Head) for his kindness in suggesting that a proposal for funding under IRPHA may be submitted. The funds from DST for a IRPHA facility in applied biocatalysis were a great enabler in carrying out later work in the area. Finally MNG will like to thank people at the Department of Biochemical Engineering and Biotechnology for providing a new "home" to continue his work in applied biocatalysis. JM thanks the Council of Scientific and Industrial Research [Govt. of India] for the Senior Research Fellowship.

Aparicio S and Alcalde R (2009) The green solvent ethyl lactate: an experimental and theoretical characterization Green Chem 11 65-78

Arnold F H and Georgiou G (2003a) Directed enzyme evolution: Screening and selection methods, Humana Press, Totowa

Arnold F H and Georgiou G (2003b) Directed evolution library construction: Methods and protocol, Humana Press, Totowa

Arora B, Mukherjee J and Gupta M N (2014b) Enzyme promiscuity: using the dark side of enzyme specificity in 
white biotechnology Sust Chem Processes 225

Arora B, Pandey P S and Gupta M N (2014a) Lipase catalysed Cannizaro type reaction with substituted benzaldehydes in water Tetrahedron Lett 55 3920-3922

Arsenault A, Cabana H and Peter Jones J (2011) Laccase-Based CLEAs: Chitosan as a Novel Cross-Linking Agent Enzym Res 2011 Article ID 376015

Axen R, Porath J and Ernback S (1967) Chemical coupling of peptides and proteins to polysaccharides by means of cyanogens halides Nature 214 1302-1304

Banerjee R, Das K, Ravishankar R, Suguna K, Surolia A and Vijayan M (1996) Conformation, protein-carbohydrate interactions and a novel subunit association in the refined structure of peanut lectin lactose complex J Mol Biol 259 281-296

Banerjee R, Shekhar S C, Ganesh V, Kalyan Das, Dhanraj V, Mahanta S K, Surolia A, Suguna K and Vijayan M (1994) Crystal structure of peanut lectin, a protein with an unusual quaternary structure Proc Natl Acad Sci USA 91 227-231

Banoth L, Singh M, Tekewe A and Banerjee U C (2009) Increased enantioselectivity of lipase in the transesterification of dl$( \pm)$-3-phenyllactic acid in ionic liquids Biocatal Biotransform 27 263-270

Berezin I V (1978) Physicochemical Aspects of Immobilized Enzyme-Matrix Interactions. In: Enzyme engineering (Pye E K and Weetall H H Eds.) Springer-Verlag, New York, pp. 115-132

Berg J M, Tymockzo J L and Stryer L (2002) Biochemistry. Freeman and Co., New York

Bittiger H and Schnebli H P (1976) Concanavalin A as a tool. John Wiley and Sons, New Jersey

Bommarius A S and Riebel B R (Eds) (2004) Biocatalysis, WileyVCH Verlag GmbH and Co., Weinheim

Boodhoo K and Harvey A (Eds) (2013) Process intensification for green chemistry: engineering solutions for sustainable chemical processing, John Wiley and Sons Ltd., U.K.

Broun G H (1997) Chemically aggregated enzymes. In: Methods in Enzymology (Mosbach K, Ed.) pp. 263-269, Academic Press, New York

Bruce L J, Ghose S and Chase H A (1999) The effect of column verticality on separation efficiency in expanded bed adsorption Bioseparation 8 69-75

Bulow L (1993) Artificial bifunctional enzymes: A tool to improve consecutive enzyme reactions and cell metabolism. In: Biocatalyst design for stability and specificity (Himmel $\mathrm{M}$ E and Gerogiou G, Eds.), ACS, Washington

Burgess R R and Deutscher M P (2009) Guide to Protein
Purification Meth Enzymol 463 405-474

Busto E, Gotor-Fernandez V and Gotor V (2010) Hydrolases: catalytically promiscuous enzymes for non-conventional reactions in organic synthesis Chem Soc Rev 39 4504-23

Cao L (2005) Carrier bound immobilized enzymes: principles, application and design, Wiley-VCH Verlag GmbH and Co., Weinheim

Cao L, van Langen L and Sheldon R A (2003) Immobilised enzymes: carrier-bound or carrier-free? Curr Opin Biotechnol 14 387-394

Carey PR (Ed) (1996) Protein engineering and design, Academic Press, New York

Carrea G and Riva S (2000) Properties and synthetic applications of enzymes in organic solvents Angew Chem Int Ed 39 2226-2254

Chang N, Hen S J and Klibanov A M (1991) Protein separation and purification in neat dimethyl sulfoxide Biochem Biophys Res Commun 176 1462-1468

Chang Y K and Chase H A (1996) Ion exchange purification of glucose-6-phosphate dehydrogenase from unclarified yeast cell homogenates using expanded bed adsorption Biotechnol Bioeng 49 204-216

Chase H A (1994) Purification of proteins by adsorption chromatography in expanded beds Trends Biotechnol 12 296-303

Chase H A and Draeger N M (1992) Affinity purification of proteins using expanded beds J Chromatogr 597 129-145

Cheetham P S J (2000) Some commercial and financial aspects of biocatalysis research and development projects. In: Applied Biocatalysis (Straathof A J J and Adlercreutz P Eds) pp. 399-433, Harwood Academic Publishers, Netherlands

Copley S D (2003) Enzymes with extra talents: moonlighting functions and catalytic promiscuity Curr Opin Chem Biol $7265-272$

Dalal S and Gupta M N (2007) Treatment of phenolic wastewater by horseradish peroxidase immobilized by bioaffinity layering Chemosphere 67 741-747

Danielsson B and Mosbach K (1988) Enzyme thermistors, Meth Enzymol: Immobilized enzymes and cells 137 181-196

Diaz-Alvarez A E, Francos J, Crochet P and Cadierno V (2014) Recent advances in the use of glycerol as green solvent for synthetic organic chemistry Curr Green Chem 1 51-65

Fexby S and Bulow L (2004) Hydrophobic peptide tags as tools in bioseparation Trends Biotechnol 22 511-516

Fjerbaek L, Christensen K V and Norddahl B (2009) A review of the current state of biodiesel production using enzymatic transesterification Biotechnol Bioeng 102 1298-1315 
Fruton J S (1970) The specificity and mechanism of pepsin action Adv Enzymol 33 401-443

Fruton J S (1976) The mechanism of the catalytic action of pepsin and related acid proteinases Adv Enzymol 44 1-36

Fruton J S (1982) Proteinase-catalyzed synthesis of peptide bonds Adv Enzymol 53 239-306

Fruton J S (1983) Proteinases as catalysts of peptide synthesis Trans New York Acad Sci 41 49-56

Fruton J S and Simmonds S (1958) General Biochemistry. John Wiley, New York

Gangadhara, Ramesh Kumar P and Prakash V (2008) Influence of polyols on the stability and kinetic parameters of invertase from Candida utilis: correlation with the conformational stability and activity Protein $\mathrm{J} 27$ 440-449

Garg N, Galaev I Y and Mattiasson B (1996) Polymer-shielded dyeligand chromatography of lactate dehydrogenase from porcine muscle in an expanded bed system Bioseparation 6 193-199

Gautam S, Dubey P, Singh P, Varadarajan R and Gupta M N (2012) Simultaneous refolding and purification of recombinant proteins by macro- (affinity ligand) facilitated three-phase partitioning Anal Biochem 430 56-64

Gekas V and Lopez-Leiva M (1985) Hydrolysis of lactose: a literature review Process Biochem 20 2-12

Godfrey T and Reichelt J (1983) Industrial enzymology: The application of enzymes in industry. Nature Press, USA

Goldsmith M and Tawfik D S (2012) Directed enzyme evolution: beyond the low-hanging fruit Curr Opin Struc Biol 22 406-412

Goldstein L and Katchalski-Katzir E (1976) Immobilized enzymes-a survey In: Immobilized enzymes principles (Wingard L B Jr, Goldstein L and Katchalski-Katzir E Eds), Vol 1, Academic Press, London, pp. 1-22

Green K D, Chen W, Houghton J L, Fridman M and GarneauTsodikova S (2010) Exploring the substrate promiscuity of drug modifying enzymes for the chemoenzymatic generation of $\mathrm{N}$-acylated amino glycosides ChemBioChem 11 119-126

Guilbault G G (1988) Enzyme electrode probes Meth Enzymol: Immobilized enzymes and cells 137(D) 14-28

Guisan J M (Ed.) (2013) Immobilization of enzymes and cells, Humana Press, New York

Guo Y and Clark D S (2001) Activation of enzymes for nonaqueous biocatalysis by denaturing concentrations of urea BBA-Protein Struct Mol Enzymol 1546 406-411

Gupta M N (1992) Enzyme function in organic solvents Eur J Biochem 203 25-32
Gupta M N (2012) Some deleterious consequences of birth of new disciplines in science: the case of biology Curr Sci 103 126-127

Gupta M N (Ed.) (2000) Methods in Non-Aqueous Enzymology. Birkhauser Verlag, Basel, Switzerland

Gupta M N (Ed.) (2002) Methods in affinity-based separation of proteins/enzymes. Birkhauser Verlag, Basel, Switzerland

Gupta M N and Mattiasson B (1992) Unique Applications of immobilized proteins in bioanalytical systems: In Bioanalytical Applications of Enzymes (Suelter C H and Kricka L Eds.) John Wiley \& Sons Inc., New York, pp 134

Gupta M N and Mattiasson B (1994) Novel technologies in downstream processing Chem Ind 9 673-675

Gupta M N and Mukherjee J (2013) Designing Nanocarriers for drug delivery. In: Nanomedicine for drug delivery and therapeutics (Mishra A Ed.), John Wiley and Sons, Salem, Massachusetts, pp 411-436

Gupta M N and Raghava S (2007) Relevance of chemistry to white biotechnology Chem Cent J 117

Gupta M N and Raghava S (2011) Enzyme stabilization via cross-linked enzyme aggregates. In: Enzyme stabilization and immobilization (Minteer S D Ed) pg. 133-145, Humana Press, New York

Gupta M N, Kapoor M, Majumder A B and Singh V (2011) Isozymes, moonlighting proteins and promiscous enzymes Curr Sci 100 1152-1162

Halling P J (1994) Thermodynamic predictions for biocatalysis in nonconventional media: theory, tests, and recommendations for experimental design and analysis Enzym Microb Technol 16 178-206

Halling P J (2000) Biocatalysis in low-water media: understanding effects of reaction conditions Curr Opin Chem Biol 4 7480

Hartman F C and Wold F (1967) Crosslinking of bovine pancreatic ribonuclease A with diadipimidate Biochemistry 6 24392448

Hermanson G T, Krishna Mallia A and Smith P K (1992) Immobilized affinity ligand techniques. Academic Press Inc., London

Hou C T (Ed) (2005) Handbook of industrial biocatalysis, Taylor and Francis Group, London

Huber R E, Gupta M N and Khare S K (1994) The active site and mechanism of beta- galactosidase from Escherichia coli. Int J Biochem 26 309-318

Hudson E P, Eppler R K and Clark D S (2005) Biocatalysis in semi-aqueous and nearly anhydrous conditions Curr Opin 


\section{Biotechnol 16 637-643}

Hult K and Berglund P (2007) Enzyme promiscuity: mechanism and applications Trends Biotechnol 25 231-238

Jaeger K E (2004) Protein technologies and commercial enzymes: white is the hype-biocatalysis on the move Curr Opin Biotechnol 15 269-271

Jain N K and Roy I (2009) Effect of trehalose on protein structure Protein Sci 18 24-36

Jeffery C J (2009) Moonlighting proteins - an update Mol Bio Syst 5 345-350

Kale S and Lali A (2011) Characterization of superporous cellulose matrix for high-throughput adsorptive purification of lysozyme Biotechnol Prog 27 1078-1090

Kamra A and Gupta M N (1987) Crosslinking Con-A DEAE cellulose-An affinity medium for Con A interacting glycoproteins Anal Biochem 164 405-410

Kamra A and Gupta M N (1988) Reaction of concanavalin A with dimethyl adipimidate: Purification and characterization of crosslinked Con A derivative with enhanced thermal stability Biochim Biophys Acta 966 181-187

Kapoor M and Gupta M N (2012) Lipase promiscuity and its biochemical applications Process Biochem 47 555-569

Kapoor M, Majumder A B and Gupta M N (2014) Promiscuous lipase-catalyzed $\mathrm{C}-\mathrm{C}$ bond formation reactions between 4-nitrobenzaldehyde and 2-cyclohexen-1-one in biphasic medium: aldol and Morita-Baylis-Hillman adduct formations Cat Lett, DOI 10.1007/s10562-014-1429-8

Karau A, Benken C, Thommes J and Kula M R (1997) The influence of particle size distribution and operating conditions on the adsorption performance in fluidized beds Biotechnol Bioeng 55 54-64

Kaushik J K and Bhat R (2003) Why is trehalose an exceptional protein stabilizer? An analysis of the thermal stability of proteins in the presence of the compatible osmolyte trehalose J Biol Chem 278 26458-26465

Khare S K and Gupta M N (1987) A crosslinked preparation of E.coli. beta- galactosidase. Appl Biochem Biotechnol 161 15

Khare S K and Gupta M N (1988a) Immobilization of E. coli beta-galactosidase and its derivatives by polyacrylamide gel Biotechnol Bioeng 31829 - 833

Khare S K and Gupta M N (1988b) Preparation of Con A betagalactosidase conjugates and its application in lactose hydrolysis J Biosci 13 47-54

Khersonsky O and Tawfik D S (2010) Enzyme promiscuity: a mechanistic and evolutionary perspective Annu Rev Biochem 79 471-505
Khmelnitsky Y L, Welch S M, Clark D S and Dordick J S (1994) Salts dramatically enhance the activity of enzymes suspended in organic solvents J Am Chem Soc 1162647 2648

Kim Y, Cunningham M A, Mire J, Tesar C, Sacchettini J and Joachimiak A (2013) NDM-1, the ultimate promiscuous enzyme: substrate recognition and catalytic mechanism FASEB J 27 1917-1927

Kosaric N and Asher Y J (1985) The utilization of cheese whey and its components. In: Advances in Biochemical Engineering/Biotechnology (Fiechter AEd.) vol 32, SpringVerlag, New York, pp. 25-60

Kreiner M, Moore B D and Parker M C (2001) Enzyme-coated micro-crystals: a 1-step method for high activity biocatalyst preparation Chem Commun 1096-1097

Kulothungan S R, Das M, Johnson M, Ganesh C, and Varadarajan R (2009) Effect of Crowding Agents, Signal Peptide, and Chaperone SecB on the Folding and Aggregation of E. coli Maltose Binding Protein Langmuir 25 6637-48

Kumar D and Bhalla T C (2004) Purification and characterization of a small size protease from Bacillus sp. APR-4 Ind $J$ Exper Biol 42 515-521

Larsson K M, Adlercreutz P and Mattiasson B (1987) Activity and stability of horse-liver alcohol dehydrogenase in sodium dioctylsulfosuccinate/cyclohexane reverse micelles Eur J Biochem 166 157-161

Lee M Y and Dordick J S (2002) Enzyme activation for nonaqueous media Curr Opin Biotechnol 13 376-384

Lesley S A (2001) High throughput proteomics: Protein expression and purification in the post genomic world Protein Exp Purif 22 159-164

Liu B, Qian X, Wu Q and Lin X (2008) Two lipase catalysed sequential synthesis of drug derivatives in organic media Enzym Microb Technol 43 375-380

Ljungar G, Adlecreutz P and Mattiasson B (1993) Reactions catalyzed by PEG-modified a-chymotrypsin in organic solvents. Influence of water content and degree of modification Biocatalysis 7 279-288

Lopez-Serrano P, Cao L, van Rantwijk F and Sheldon R A (2002) Crosslinked enzyme aggregates with enhanced activity: application to lipases Biotechnol Lett 24 1379-1383

Lou F W, Liu B K, Wu Q, Lv D S and Lin X F (2008) Candida Antarctica lipase (CALB)-catalysed carbon-sulphur bond addition and controllable selectivity in organic media $A d v$ Synth Catal 350 1959-1962

Luisi P L (1985) Enzymes Hosted in Reverse Micelles in Hydrocarbon Solution Angew Chem Int Ed Engl 24 439450 
Majumder A B and Gupta M N (2011) Increasing catalytic efficiency of Candida rugosa lipase for the synthesis of tert-alkyl butyrates in low water media Biocatal Biotransform 29 238-245

Majumder A B and Gupta M N (2014) Lipase-Catalyzed Condensation Reaction of 4-nitrobenzaldehyde with acetylacetone in aqueous organic co solvent mixtures and in nearly anhydrous media Synth Commun 44:6 818-826

Majumder A B, Mondal K, Singh T P and Gupta M N (2008) Designing crosslinked lipase aggregates for optimum performance as biocatalysts Biocatal Biotransform 26235 242

Majumder A B, Singh B and Gupta M N (2007) Diastereoselective synthesis of (R)-(alkyl)- $\beta$-D-galactopyranoside by using $\beta$-galactosidase (Aspergillus oryzae) in low-water media Bioorg Med Chem Lett 18 124-128

Manjunath P, Shenoy B C and Raghavendra Rao M R (1983) Fungal glucoamylases J Appl Biochem 5 235-260

Martinek K and Mozhaev V V (1993) Need for thermostability, its benefits and main strategies for thermostabilization. In: Thermostability of enzymes (Gupta M N Ed.), Springer Verlag, Heidelberg, pp. 76-83

Mateo C, Palomo J M, van Langen L M, van Rantwijk F and Sheldon R A (2004) A new, mild cross-linking methodology to prepare cross-linked enzyme aggregates Biotechnol Bioeng 86 273-276

Mattiasson B (1988) Affinity immobilization Meth Enzymol: Immobilized enzymes and cells 137(D) 647-656

Mattiasson B (Ed.) (1983) Immobilized Cells and Organelles, CRC Press, Boca Raton, FL, vol. 1-2

Mattiasson B (ed.) (1999) Expanded Bed Chromatography, Kluwer Academic Publishers, The Netherlands

Mattiasson B and Adlercreutz P(1991) Tailoring the microenvironment of enzymes in water-poor systems Trends Biotechnol 9394

Mbrabet N T and Vijaylakshmi M A (2002) Immobilized metalion chromatography: from phenomenological hallmarks to structure based molecular insights. In: Vijaylakshmi M A (Ed.), Biochromatography. Theory and Practice. Taylor and Francis, New York, pp. 272-294

McCreath G E, Chase H A and Lowe C R (1994) Novel affinity separations based on perfluorocarbon emulsions. Use of a perfluorocarbon affinity emulsion for the direct extraction of glucose-6-phosphate dehydrogenase from homogenized baker's yeast $J$ Chromatogr A 659: 275-287

Means G E and Feeney R E (1990) Chemical modification of proteins: history and applications Bioconj. Chem 1 2-12
Minteer S D (Ed.) (2011) Enzyme stabilization and immobilization: methods and protocols, Humana Press, New York

Mondal K and Gupta M N (2006) The affinity concept in bioseparation: Evolving paradigms and expanding range of applications Biomolecular Engineering 23 59-76

Mondal K, Roy I and Gupta M N (2006) Affinity based strategies for protein purification. Anal Chem 78 3499-3504

Mondal K, Sharma A and Gupta M N (2003) Macro-(affinity ligand) facilitated three phase partitioning (MLFTPP) for purification of glucoamylase and pullulanase using alginate. Protein Expr Purif 28 190-195

Mosbach K (1980) Immobilized Enzymes Trends Biochem Sci 5 $1-3$

Mosbach K (Ed) (1976) Immobilized enzymes, Meth. Enzymol. XLIV, Academic Press Inc, New York

Mozhaev V V, Berezin I V and Martinek K (1987) Reactivation of Immobilized Enzymes Methd Enzymol 135 586-596

Mukherjee J and Gupta M N (2012) Alpha chymotrypsin coated clusters of $\mathrm{Fe}_{3} \mathrm{O}_{4}$ nanoparticles for biocatalysis in low water media Chem Cent J 6 1-12

Mukherjee J, Mishra P and Gupta M N (2015) Urea treated subtilisin as a biocatalyst for transformations in organic solvents Tetrahedron Lett 56 1976-1981

Nelson D L and Cox M M (2009) Lehninger Principles of Biochemistry. W.H. Freeman \& Company; 5th edition, New York

Nilsson K and Mosbach K (1981) Immobilization of enzymes and affinity ligands to various hydroxyl group carrying supports using highly reactive sulfonyl chlorides Biochem Biophys Res Commun 102 449-457

Nosoh Y and Sekiguchi T (1993) Protein engineering for thermostabilization. In: Thermostabilization of enzymes (Gupta M N Ed.), Springer-Verlag, Heidelberg, pp. 182204

O'Shannessy D J and Hoffman W L (1987) Site-Directed Immobilization of Glycoproteins on Hydrazide-Containing Solid Supports Biotechnol Appl Biochem 9 488-496

Okahata Y and Mori T (1997) Lipid coated enzymes as efficient catalysis in organic media Trends Biotechnol 15 50-54

Orlich B and Schomäcker R (2002) Enzyme catalysis in reverse micelles Adv Biochem Eng Biotechnol 75 185-208

Owen R O and Chase H A (1997) Direct purification of lysozyme using continuous counter-current expanded bed adsorption J Chromatogr A 757 41-49

Parmar V S, Prasad A K, Pati H N, Kumar R, Azim A, Roy S and Errington W (1999) Enzyme catalyzed chemoselective 
transesterification reactions on hydroxymethylated phenolic compounds Bioorg Chem 27 119-134

Partridge J, Halling P J and Moore B D (1998) Practical route to high activity enzyme preparations for synthesis in organic media Chem Commun 841-842

Patel R N (Ed.) (2000) Stereoselective Biocatalysis. Marcel Dekker: New York

Polaina J and MacCabe A P (Eds) (2007) Industrial enzymes: Structure, function and applications, Springer, Netherlands

Porath J, Carlsson J, Olsson I and Belfrage G (1975) Metal chelate affinity chromatography: A new approach to protein fractionation Nature 258 598-599

Przybycien T M, Pujar N S and Steele L M (2004) Alternative bioseparation operations: life beyond packed-bed chromatography Curr Opin Biotechnol 15 469-478

Raghava S, Barua B, Singh P K, Das M, Madan L, Bhattacharyya S, Bajaj K, Gopal B, Varadarajan R and Gupta M N (2008) Refolding and simultaneous purification by three phase partitioning of recombinant proteins from inclusion bodies Protein Sci 17 1987-1997

Rajput Y S and Gupta M N (1988a) Reaction of trypsin with dimethyl adipimidate: Purification and characterization of a trypsin derivative with decreased autolysis Enzym Microb Technol 10 143-150

Rajput Y S and Gupta M N (1988b) Preparation of heteroenzyme conjugates: trypsin-chymotrypsin and trypsin - alkaline phosphatase Biotechnol Appl Biochem 10 242-250

Ramanathan K, Jonsson B R and Danielsson B (2000) Analysis in non aqueous milieu using thermistors. In: Methods in non aqueous enzymology (Gupta M N Ed), Birkhauser Verlag, Basel, pp. 174-194.

Rastogi N, Singh A, Pandey S N, Sinha M, Bhushan A, Kaur P and Singh TP (2014) Structure of the iron-free true Cterminal half of bovine lactoferrin produced by tryptic digestion and its functional significance in the gut FEBS J 281 2871-2872

Rather G M, Mukherjee J, Halling P J and Gupta M N (2012) Activation of alpha chymotrypsin by three phase partitioning is accompanied by aggregation PLOS ONE 7 e49241

Ringe D (1995) What makes a binding site a binding site? Curr Opin Struct Biol 5 825-829

Roy I and Gupta M N (2001) Purification of a 'double-headed' inhibitor of alpha-amylase/proteinase $\mathrm{K}$ from wheat germ by expanded bed chromatography Bioseparation 9239 245

Roy I and Gupta M N (2002a) Downstream processing of enzymes/proteins Proc Ind Natl Sci Acad (B) B 68 175-
204

Roy I and Gupta M N (2002b) Purification of a bacterial pullulanase on a fluidized bed of calcium alginate beads $J$ Chromatogr A 950 131-137

Roy I and Gupta M N (2002c) Unexpected affinity of polysaccharides and its application in separation of enzymes on fluidized beds Sep Sci Technol 37 1591-1610

Roy I and Gupta M N (2004a) Freeze drying of proteins: some emerging concerns Biotechnol Appl Biochem 39 165-177

Roy I and Gupta M N (2004b) Preparation of highly active alpha-chymotrypsin for catalysis in organic media Bioorg Med Chem Lett 14 2191-2193

Roy I, Sardar M and Gupta M N (2005) Crosslinked alginateguar gum beads as fluidized bed affinity media for purification of jacalin Biochem Eng J 23 193-198

Roy I, Sastry M S R, Johri B N and Gupta M N (2001) Purification of alpha amylase isoenzymes from Scytalidium thermophilum on a fluidized bed of alginate beads followed by Concanavalin A-agarose column Protein Expr Purif $\mathbf{2 0}$ 162-168

Roy I, Sharma A and Gupta M N (2004) Obtaining higher transesterification rates with subtilisin Carlsberg in nonaqueous media Bioorg Med Chem Lett 14 887-889

Roy I, Mondal K and Gupta M N (2006) Leveraging protein purification strategies in proteomics J Chromatogr B Analyt Technol Biomed Life Sci 849 32-42

Sachdev G P and Fruton J S (1975) Kinetics of action of pepsin on fluorescent peptide substrates Proc Natl Acad Sci USA 72 3424-3427

Sadana A (1991) Biocatalysis: Fundamentals of Enzyme Deactivation Kinetics, Prentice Hall, New Jersey

Sadana A (1993) Models of Enzyme Deactivation. In: Gupta, M.N. (Ed.), Thermostability of Enzymes, Springer Verlag, Heidelberg, Germany

Saha P, Barua B, Bhattacharyya S, Balamurali M M, Schief W R, Baker D and Varadarajan R (2011) Design and characterization of stabilized derivatives of human CD4D12 and CD4D1 Biochemistry 50 7891-900

Saleemuddin M (1999) Bioaffinity Based Immobilization of Enzymes Adv Biochem Eng/Biotechnol 64 203-226

Saleemuddin M and Husain Q (1991) Concanavalin A: A useful ligand for glycoenzyme immobilization-A review Enzyme Microb Technol 13 290-295

Salunke D M, Joginadha Swamy M, Islam Khan M, Mande S C, Surolia A and Vijayan M (1985) Arrangement of Subunits in Peanut Lectin J Biol Chem 260 13576-13579

Sankaranarayanan R, Sekar K, Banerjee R, Sharma V, Surolia A 
and Vijayan M (1996) A novel mode of carbohydrate recognition in jacalin, a Moraceae plant lectin with a prism fold Nat Struc Biol 3 596-603

Sardar M and Gupta M N (2005) Immobilization of tomato pectinase on Con A-Seralose 4B by bioaffinity layering Enzym Microb Technol 37 355-359

Satyanarayana T and Kunze G (Eds) (2009) Yeast Biotechnology: Diversity and applications, Springer, New York

Schoevaart R, Wolbers M W, Golubovic M, Ottens M, Kieboom A P G, van Rantwijk F, van der Wielen LA M and Sheldon R A (2004) Preparation, optimization and structures of cross-linked enzyme aggregates (CLEAs) Biotechnol Bioeng 87 754-762

Scopes R K (1994) Protein Purifications: principles and Practice. Springer Science + Business Media, LLC, California, USA

Sell D and Ulber R (Eds.) (2006) Advances in Biochemical and Engineering/ Biotechnology, Springer, New York

Shah S and Gupta M N (2007) Kinetic resolution of (+/-)-1phenylethanol in $[\mathrm{Bmim}]\left[\mathrm{PF}_{6}\right]$ using high activity preparations of lipases Bioorg Med Chem Lett 17 921-924

Shah S and Gupta M N (2007) Obtaining high transesterification activity for subtilisin in ionic liquids Biochim Biophys Acta 1770 94-98

Shah S, Sharma A and Gupta M N (2006) Preparation of crosslinked enzyme aggregates by using bovine serum albumin as a proteic feeder Anal Biochem 351 207-213

Shah S, Sharma A and Gupta M N (2008) Cross-linked protein coated microcrystals as biocatalysts in non-aqueous solvents Biocatal Biotransform 26 266-271

Sharma K K, Sharma S, Karp M and Kuhad R C (2012). Ligninolytic enzymes improve soil DNA purity: Solution to methodological challenges of soil metagenomics $\mathrm{J} \mathrm{Mol}$ Catal B: Enzym 83 73-79

Sharma P, Dube D, Sinha M, Mishra B, Dey S, Mal G, Pathak K M L, Kar P, Sharma S and Singh T P (2011) Multiligand specificity of pathogen associated molecular-binding site in peptidoglycan recognition protein J Biol Chem $\mathbf{2 8 6}$ 31723-31730

Sharma S, Roy I and Gupta M N (2001) Separation of phospholipase $\mathrm{D}$ from peanut on a fluidized bed of crosslinked alginate beads Biochem Eng J 8 235-239

Sheldon R A (2007) Enzyme Immobilization: The Quest for Optimum Performance Adv Synth Catal 349 1289-1307

Sheldon R A, Schoevaart R and van Langen L M (2005) Crosslinked enzyme aggregates (CLEAs): A novel and versatile method for enzyme immobilization (a review) Biocatal Biotransform 23 141-147

Singh R K, Gourinath S, Sharma S, Roy I, Gupta M N, Betzel C,
Srinivasan A and Singh T P (2001) Enhancement of enzyme activity through three-phase partitioning: crystal structure of a modified serine proteinase at 1.5 A resolution Protein Eng 14 307-313

Skaugrud O, Hagen A, Borgersen B and Dornish M (2013) Biomedical and pharmaceutical applications of alginate and chitosan Biotechnol Genet Eng Rev 16 23-40

Skolnick J and Gao M (2013) Interplay of physics and evolution in the likely origin of protein biochemical function Proc Natl Acad Sci 110 9344-9349

Solanki K and Gupta M N (2008) Optimizing biocatalyst design for obtaining high transesterification activity by achymotrypsin in non-aqueous media Chem Cent J 2 1-7

Solanki K and Gupta M N (2011) Simultaneous purification and immobilization of Candida rugosa lipase on superparamagnetic $\mathrm{Fe}_{3} \mathrm{O}_{4}$ nanoparticles for catalyzing transesterification reactions New J Chem 35 2551-2556

Solanki K, Gupta M N and Halling P J (2012) Examining structureactivity correlations of some high activity enzyme preparations for low water media Bioresour Technol 115 $147-51$

Solomon B, Koppel R and Katchalski-Katzir E (1984b) Use of a specific Monoclonal Antibody for the Preparation of a Highly Active Immobilized Carboxypeptidase A Biotechnology 2 709-712

Solomon B, Koppel R, Pines G and Katchalski-Katzir E (1986) Enzyme immobilization via monoclonal antibodies I. Preparation of a highly active immobilized carboxypeptidase A Biotechnol Bioeng 28 1213-1221

Solomon B, Moav N, Pines G and Katchalski-Katzir E (1984a) Interaction of carboxypeptidase a with monoclonal antibodies Mol Immunol 21 1-11

Soskine M and Tawfik D S (2010) Mutational effects and the evolution of new protein functions Nature Rev Genet 11 $572-582$

Sousa I T and Angela-Taipa M (2014) Biomimetic affinity ligands for protein purification. In: Protein downstream processing: design, development and application of high and low resolution methods (Labrou N L Ed.). Humana Press, New Yprk, pp. 231-262

Sowdhamini P and Balaram P (1993) Protein structure and stability. In: Thermostability of Enzymes (Gupta M N Ed.), Springer Verlag, Heidelberg, pp. 2-23

Srere PA, Mattiasson B and Mosbach K (1973) An Immobilized Three-Enzyme System: A Model for Microenvironmental Compartmentation in Mitochondria Proc Nat Acad Sci USA 70 2534-2538

Stites D P and Terr A IEds. (1991) Basic and Clinical Immunology, 
Prentice-Hall Int. Inc. New York

Straathof A A and Adlercreutz P (Eds.) (2000) Applied Biocatalysis. Harwood Academic Publishers, Amsterdam

Talekar S, Ghodake V, Ghotage T, Rathod P, Deshmukh P, Nadar S, Mulla M, Ladole M (2012) Novel magnetic cross-linked enzyme aggregates (magnetic CLEAs) of alpha amylase Bioresour Technol 123 542-547

Taneja S and Ahmad F (1994) Increased thermal stability of proteins in the presence of amino acids Biochem $J \mathbf{3 0 3}$ 147-153

Tyagi R and Gupta M N (1998) Chemical modification and chemical crosslinking for protein/ enzyme stabilization Biochemistry (Moscow) 63 334-344

van Ee J H, Misset O and Baas E J (Eds) (2010) Enzymes in detergency, CRC Press, Boca Raton

Verma D, Kawarabayasi Y, Miyazaki K and Satyanarayana T (2013) Cloning, Expression and Characteristics of a Novel Alkalistable and Thermostable Xylanase Encoding Gene (Mxyl) Retrieved from Compost-Soil Metagenome Plos One 8 e52459

Vijayalakshmi M A (2002) Biochromatography: Theory and Practice. Taylor and Francis: London

Vulfson E N, Halling P J and Holland H L (Eds.) (2001) Enzyme in non aqueous solvents: methods and protocols. Humana Press, New York

Walker J M (Ed.) (2002) The Protein Protocols Handbook. Humana Press, New Jersey

Walter H and Brooks D E (1985) Partitioning in aqueous two phase systems: theory, methods, uses and applications to biotechnology, Academic Press Inc., London

Watanabe K, Yamagiwa N and Torisawa Y (2007) Cyclopentyl
Methyl Ether as a New and Alternative Process Solvent Org Process Res Dev 11 251-258

Wold F (1972) Bifunctional Reagents Meth Enzymol 25 623-651

Wong S S (1991) Chemistry of protein conjugation and crosslinking. CRC Press, Florida

Wright J H and Evans D A(Eds) (2008) New research on biofuels, Nova Sci Publishers Inc., New York

Wu S-H, Chu F-Y and Wang K-T (1991) Reversible enantioselectivity of enzymatic reactions by media Bioorg Med Chem Lett 1 339-342

www.acs.org/content/acs/en/pressroom/newsreleases/2008/ december/waste-coffee-grounds-offer-new-source-ofbiodiesel-fuel.html

www.gelifesciences.com/file_source/GELS/Service\% 20and\%20 Support/Documents\%20and\% 20Downloads/Handbooks/ pdfs/Multimodal\%20 Chromatography.pdf

www.researchtriangle.org/news-and-events/novozymescompletes-expansion-us-pilot-plant

www.sigmaaldrich.com/catalog/product/sigma/30079?lang= en\&region $=\mathrm{IN}$

Yadav S and Ahmad F (2000) A new method for the determination of stability parameters of proteins from their heat-induced denaturation curves Anal Biochem 283 207-213

Yaropolov A I, Karyakin AA, Varfolomeyev S D and Berezin I V (1984) Mechanism of $\mathrm{H}_{2}$-electrooxidation with immobilized hydrogenase Bioelectrochem Bioenerg 12 267277

Zaks A and Klibanov A M (1984) Enzymatic catalysis in organic media at 100 degrees C Science 224 1249-1251

Zaks A and Klibanov A M (1988) Enzymatic catalysis in nonaqueous solvent J Biol Chem 263 3194-3201. 